\title{
Prevalence and determinants of male partner violence against Mexican women: A population-based study
}

\author{
Leonor Rivera-Rivera, MD, MSC, ${ }^{(1)}$ Eduardo Lazcano-Ponce, MD, MSc, Dr Sc, ${ }^{(1)}$ \\ Jorge Salmerón-C astro, MD, MSc, Dr Sc, ${ }^{(2)}$ Eduardo Salazar-Martínez, MD, MSc, Dr Sc, ${ }^{(1)}$ \\ Roberto Castro, MA, PhD, ${ }^{(3)}$ Mauricio Hernández-Avila, MD, MSc, D r Sc.(1)
}

Rivera-Rivera L, Lazcano-Ponce E, Salmerón-Castro J, Salazar-Martínez E, Castro R, Hernández-Avila M. Prevalence and determinants of male partner violence against Mexican women: A population-based study.

Salud Publica Mex 2004;46:113-122. The English version of this paper is available too at: http://www.insp.mx/salud/index.html

\begin{abstract}
A bstract
Objective To determine the prevalence of and risk factors for vio lence against wo men, inflicted by their male partners, in a representative sample of women residing in the metropolitan area of C uernavaca Morelos, Mexico. Material and Methods A population-based study was conducted from June to September 1998, among 1535 women aged 15 to 49 years. Principal components analysis was used to determine the domains of violence that served as the dependent variable. Polynomial logistic regression models were used to estimate odds ratios (OR), with $95 \%$ confidence intervals $(\mathrm{Cl})$. Results Prevalence of low-moderate level violence was $35.8 \%$, while prevalence of severe violence was $9.5 \%$. The lifetime prevalence of reported rape was $5.9 \%$. The main factors associated with violence were socio-economic status ( $0 \mathrm{R}=0.57 ; 95 \% \mathrm{Cl}=0.34-0.95)$; education level, both of the women studied (test for trend $p=0.01$ ) and of the male partner (test for trend $p=0.002$ ); number of years living with partner ( $\mathrm{OR}=2.63 ; 95 \% \mathrm{Cl}=1.55-4.45)$, alcohol use $(0 \mathrm{R}=2.56 ; 95 \% \mathrm{Cl}=2.02-3.25)$, illegal drug use by partner $(0 \mathrm{R}=6.17 ; 95 \% \mathrm{Cl}=2.37-16.03)$; violence during childhood $(\mathrm{OR}=3.40 ; 95 \% \mathrm{Cl}=2.23-5.18)$, and a history of rape $(0 \mathrm{R}=5.89 ; 95 \% \mathrm{Cl}=2.78-12.5)$. Conclusions. Study findings confirm that violence against women is a
\end{abstract}

Rivera-Rivera L, Lazcano-Ponce E, Salmerón-Castro J, Salazar-Martínez E, Castro R, Hernández-Avila M. Prevalencia y determinantes de violencia de pareja masculina en contra de mujeres mexicanas: un estudio con base poblacional.

Salud Publica Mex 2004;46:113-122.

El texto completo en inglés de este artículo también está disponible en: http://www.insp.mx/salud/index.html

\section{Resumen}

O bjetivo. D eterminar la prevalencia y los factores de riesgo en violencia contra mujeres por parte de sus parejas, en una muestra representativa de aquéllas residentes en el área metropolitana de Cuernavaca, Morelos, México. Material y métodos De junio a septiembre de 1998 se realizó un estudio con base poblacional en 1535 mujeres, de 15 a 49 años de edad. Para construir la variable dependiente se realizó análisis de componentes principales y, adicionalmente, análisis de regresión lo gística politómica, de lo cual se obtuvieron estimadores de razón de momios (RM), con intervalos de confianza (IC 95\%). Resultados. La prevalencia de violencia leve-moderada fue de $35.8 \%$, y de severa $9.5 \%$. La prevalencia de violación fue de $5.9 \%$. Los principales factores asociados con violencia fueron los siguientes: nivel socioeconómico ( $R M=0.57 ;$ IC 95\%=0.34-0.95); nivel educativo en ambas mujeres (prueba de tendencia $p=0.01$ ) y sus $p a-$ rejas (prueba de tendencia $p=0.002$ ); años de convivir con la pareja (RM $=2.63$; IC $95 \%=1.55-4.45)$, uso de alcohol y drogas ilegales $(R M=2.56$; IC $95 \%=2.02-3.25, R M=6.17$; IC $95 \%=2.37-16.03$, respectivamente); violencia durante la niñez ( $R M=3.40$; IC 95\%=2.23-5.18) e historia de violación $(R M=5.89 ; I C \quad 95 \%=2.78-12.5)$. Conclusiones. Este estudio confirma cómo la violencia en contra de las mujeres es

(1) Centro de Investigación en Salud Poblacional, Instituto N acional de Salud Pública. Cuernavaca, Morelos, México.

(2) Instituto Mexicano del Seguro Social, Cuernavaca, Morelos, México.

(3) Centro Regional de Investigación Multidisciplinaria, Universidad N acional Autónoma de México. Cuernavaca, Morelos, México.

Received on: February 19,2003 • Accepted on: September 30, 2003

Address reprint requests to: Leonor Rivera Rivera. Centro de Investigación en Salud Poblacional, Instituto N acional de Salud Pública. A venida Universidad 655, colonia Santa MaríaA huacatitlán, 62508 Cuernavaca, Morelos, México.

E-mail: Irivera@correo.insp.mx 
prevalent phenomenon in Mexico. A wareness-raising campaigns abo ut male partner violence should bring this important issue to the front of public discussion. Such efforts will help assure that future generations do not experience partner violence to the extent that contemporary Mexican women do.The English version of this paper is available to 0 at: http://www.insp.mx/salud/index.html

Key words: partner violence, gender, women, prevalence; Mexico un fenómeno prevalente en México. Las campañas de concienciación sobre violencia masculina se deben llevar a discusión pública. Los esfuerzos ayudarán a asegurar que las futuras generaciones de mujeres no experimenten violencia de pareja. El texto completo en inglés de este artículo también está disponible en: http://www.insp.mx/salud/ index.html

Palabras clave: violencia de pareja; genero; mujeres; prevalencia; M éxico
V iolence against women is a serious public health problem throughout the world. ${ }^{1}$ Studies carried out in a number of countries indicate that $25 \%$ to $50 \%$ of women have suffered physical abuse from a current or past partner. ${ }^{2}$ In spite of the scarcity of information about partner violence in Mexico, existing data suggest that violence against women violates their human rights and seriously endangers their health and wellbeing. Some studies have estimated that between $30 \%$ and $60 \%$ of Mexican women have suffered some type of violence from their partner. ${ }^{3-6}$

One of the major challenges encountered in the epidemiologic study of violence is variable measurement. Different ways of measuring violence have been proposed and it is often difficult to decide which measurement scale is best. The Conflict Tactics Scale (CTS), designed by Straus ${ }^{7}$ is among the scales most frequently used. Another scale, proposed by Hudson, ${ }^{8}$ measures the severity or magnitude of physical and non physical violence.

Violence against women by their male partners is a complex phenomenon determined by many factors. ${ }^{2,9,10}$ For example, victimization during childhood on the part of both the victim and the perpetrator of violence increases the probability of being part of violent acts during adulthood. ${ }^{11-14}$ Other studies have demonstrated that alcohol and illegal drug use by the perpetrator are associated with abusive behavior. ${ }^{15,16-18}$ Nevertheless, little is known about the determinants of partner violence in Mexico. The present study used data from a representative sample of the population of the city of Cuernavaca, Morelos, Mexico, to estimate the prevalence of male partner violence against women of reproductive age and to explore its determinants.

\section{Material and Methods}

From June to September 1998 a population-based study was carried out using a probabilistic sample of reproductive age women (15-49 years) living in the met- ropolitan area of Cuernavaca. The population was selected using a household sampling frame that included all houses in Cuernavaca, according to the 1995 census. All 1641 women in the random sample who had a male partner either at the time of the study or previously were invited to participate in the study. Of these women, 1535 (93.5\%) agreed to participate and signed informed consent forms after the study was explained for them.

The women who participated were interviewed in private, when no family member was present. Usually, the interview took place in their own home or in any other place where they felt comfortable. The questionnaires were applied by a female field worker trained in survey administration, as well as in providing emotional support and referrals for health care and legal protection to violence victims. All women interviewed received both counseling and information about the existing service centers for violence victims, including a pamphlet with contact information for these centers.

The questionnaires addressed three general categories. First, participants were asked about sociodemographic characteristics (i.e., age, education, number of family members, marital status); housing characteristics (i.e., construction materials, availability of drinking water); and ownership of household appliances (i.e., television, video cassette player, stove, refrigerator, heater, automobile). As has been done in other population-based studies in Mexico, ${ }^{19-20}$ we used several of these variables to construct an indicator of socioeconomic status (i.e., being a home owner, number of household inhabitants, number of bedrooms, gas-powered water heater, availability of drinking water and sewer system, education level of head of the family and having a TV, a VCR, and a car).

Second, participants were asked about their gynecologic and obstetric health and lifestyle factors (i.e., age at time of first sexual intercourse, number of pregnancies, number of births) and about their current or 
most recent male partner (i.e., time living with partner, alcohol and illegal drug use).

Finally, information was collected about the type of partner violence experienced in the previous year of her relationship with her most recent partner, the frequency of such violence, the circumstances surrounding any acts of violence, and any protective measures taken by the women to prevent future violence. Study participants were asked 22 questions about the frequency with which each act of violence occurred during the last year of cohabitation (Appendix 1). Based on findings from exploratory studies in this population, the most relevant questions about violence from the $\mathrm{CTS}^{7}$ were included, as well as from the Index of Spousal Abuse (ISA), ${ }^{8}$ however, to capture all relevant features of this phenomenon, some other questions not included in these scales were also used.

Outcome variables that expressed degrees of partner violence were derived using three different methods. In the first phase, factor analysis was carried out on 22 frequency of violence questions, using the principal components analysis method to determine the number of dimensions that characterize experiences of violent acts. Orthogonal varimax rotation was used because it is an efficient procedure for maximizing the variance of loading for each factor. The conventional standard of eigenvalues $>1$ was used to determine the number of components that should be retained. Afterwards, these results were confirmed by means of a Greigen plot (where Eigenvalues approached zero after orthogonal variance rotation). The results of these analyses suggest that the experience of male partner violence primarily falls into three domains. The first component represented low-level acts of emotional and physical violence (e.g., control of activities, not allowing women to have a job, insults, and face slaps); it accounted for $45.2 \%$ of the total common variance. Items loading onto the second component were indicators of more serious physical violence, including having been struck with an object, burned, or locked up. This component accounted for $10 \%$ of the total item variance. Finally, the items that loaded onto the third component represented extremely serious physical or emotional violence, such as strangling attempts and threats with a knife or gun. This component accounted for $6 \%$ of the total item variance. The overall percentage of variance accounted for by these three factors was $61.5 \%$. The factor loadings corresponding to each violence category were strong, and there is little evidence of cross-loading of items onto more than one factor (Table I). Moreover, inter-item reliability of the factors was high: 0.90 for the first factor and 0.80 for

Table I

Factor structure of violence:Varimax rotation. Study about male patner violence against Mexican women. Cuernavaca, morelos, Mexico, 1998

\begin{tabular}{|c|c|c|c|}
\hline Items & Factor 1 & Factor 2 & Factor 3 \\
\hline He wouldn't give you money, or he took your money & 0.65 & 0.19 & 0.02 \\
\hline He tried to control you in your activities & 0.72 & 0.04 & 0.03 \\
\hline He prevented you from going to school or work & 0.65 & -0.04 & 0.07 \\
\hline He insulted you, swore at you or humiliated you verbally & 0.82 & 0.13 & 0.15 \\
\hline He destroyed things which belonged to you & 0.62 & 0.25 & 0.25 \\
\hline He threatened to hit you with his fists & 0.78 & 0.30 & 0.22 \\
\hline He threatened to hurt you or your family or friends & 0.44 & 0.28 & 0.39 \\
\hline He pushed or shook you & 0.79 & 0.27 & 0.19 \\
\hline He slapped you & 0.74 & 0.38 & 0.17 \\
\hline He hit you with an object & 0.39 & 0.60 & 0.39 \\
\hline He hurt you badly enough that you needed medical attention & 0.21 & 0.74 & 0.38 \\
\hline He hurt you badly enough that you could not carry out your work or daily activities & 0.27 & 0.67 & 0.37 \\
\hline He burned you & 0.09 & 0.67 & -0.09 \\
\hline He locked you up & 0.08 & 0.63 & 0.11 \\
\hline He tried to strangle you & 0.18 & 0.34 & 0.68 \\
\hline He threatened you with a knife or gun & 0.15 & 0.15 & 0.78 \\
\hline He threatened to kill you & 0.24 & 0.38 & 0.69 \\
\hline He cut you with a knife or shot at you with a gun & 0.05 & -0.04 & 0.82 \\
\hline Eigenvalue & 9.51 & 2.10 & 1.30 \\
\hline Cronbach's alpha & 90.0 & 80.0 & 80.0 \\
\hline$\%$ of cumulative variance & 45.29 & 55.30 & 61.50 \\
\hline
\end{tabular}


both the second and the third factor, as indicated using Cronbach's alpha. Hence, these analyses indicate that these three factors are mutually exclusive and merit study as separate outcomes.

In the second phase, variables for use in determining the prevalence of violence were constructed. Women who reported experiencing any low or moderate acts of violence were considered prevalent cases of lowlevel violence. Women reporting high-level acts of violence were considered prevalent cases of severe violence.

In the third phase, scores were combined across the three levels of violence to create an ordered categorical variable. Women who reported experiencing no partner violence served as the reference group in further analyses. Women reporting low or moderate, but not severe violence were classified in the low-violence group, and women who reported severe violence were classified into other groups (i.e., $0=$ no violence, $1=$ lowmoderate levels of violence, $2=$ severe violence).

The question about forced sexual relations with a partner was not included in the principal components analysis; nonetheless, $11 \%$ of the women in the study reported having experienced rape. This event was explored independently.

Univariate analyses were run to determine the distribution of the variables of interest, as well as the prevalence of experiencing partner violence. Next, multivariate models were run using polynomial logistic regression to obtain age-adjusted odds ratios (OR) and $95 \%$ confidence intervals (CI) which indicated associations between potential risk factors and each of the three categories of violence. Finally, multiple polynomial logistic regression models controlled for confounding variables.

\section{Results}

A total of 1535 women participated, all of whom had a history of having lived with a male partner. The average age of study women was 33.5 years (standard deviation, $\mathrm{SD}=8.7$ )

Prevalence of low/moderate-level violence was $35.8 \%$ (95\% CI=33.4-38.2), while prevalence of severe violence was $9.5 \%$ (95\% CI=8.1-11.1). Self-reported lifetime prevalence of rape perpetrated by someone who was not a partner was 5.9\% (95\% CI=4.7-7.2). Across groups of women who experienced different levels of partner violence, statistically significant differences were found in age, education, years of cohabitation with the male partner, number of pregnancies, and age at time of first sexual intercourse (Table II).
The multivariate model adjusted for age, alcohol and illegal drug use by the male partner, history of violence during childhood, and history of sexual violence. Socioeconomic status was inversely proportional to violence (test for trend $p=0.002$ ), principally when comparing women who had not experienced partner violence with those who had experienced severe violence $(\mathrm{OR}=0.57 ; 95 \% \mathrm{CI}=0.34-0.95)$. A similar inverse relationship was found when examining education level, both for study women (test for trend $p=0.01$ ) and their male partners (test for trend $p=0.002$ ) (Table III). The number of cohabitation years was positively associated with having been subject to violence (test for trend $p=0.007$ and $p<0.001$ ). A marked increase in the odds of having experienced violence was found for women cohabitating for 11 years or more, principally in terms of experiencing severe violence (OR=2.63; $95 \%$ $\mathrm{CI}=1.55-4.45)$. Models to determine the male partner variables that were associated with violence were adjusted for age, socioeconomic status, history of violence during childhood and a history of rape. Statistically significant male partner variables included alcohol use, in relation to both low and severe-level violence $(\mathrm{OR}=2.56,95 \% \mathrm{CI}=2.02-3.25$; and $\mathrm{OR}=3.47 ; 95 \%$ $\mathrm{CI}=2.23-5.40$, respectively), and drug use, in relation to severe violence $(\mathrm{OR}=6.17 ; 95 \% \mathrm{CI}=2.37-16.03)$.

Women who reported having been victims of violence by a family member during childhood were more likely to have been victims of violence from their partner during their adult life, as compared with women who had not experienced violence during their childhood. This held true both for low-moderate level violence $(\mathrm{OR}=2.61 ; 95 \% \mathrm{CI}=2.03-3.36)$ and for severe violence $(\mathrm{OR}=3.40 ; 95 \% \mathrm{CI}=2.23-5.18)$.

The women who reported a history of rape by someone other than their male partner -an unknown aggressor being the most common- were more likely to be victims of violence from their partners, specifically in the severe violence category $(\mathrm{OR}=5.89 ; 95 \%$ $\mathrm{CI}=2.78-12.5$ ) (Table III). This analysis was adjusted for age, socioeconomic status, alcohol and drug use, history of violence during childhood, and history of rape.

Among the reproductive factors associated with violence was the number of pregnancies, with a greater number of pregnancies associated with experiencing a higher frequency of violence (test for trend $p=0.001$ ). We also observed an inverse trend between violence and age at first sexual intercourse; that is, when first intercourse occurred at older ages, violence was significantly lower (respectively, test for trend $p=0.01$ and test for trend $p=0.03$ ) (Table III). This analysis was adjusted for age, socioeconomic status, alco- 
Table II

\section{Characteristics of Women participating in the study about male partner Violence} against Mexican women. Cuernavaca, Morelos, Mexico, 1998

\begin{tabular}{|c|c|c|c|c|c|c|c|}
\hline \multirow[t]{2}{*}{ Variables } & \multirow{2}{*}{$\begin{array}{c}\text { Total }(n=1535) \\
\text { Freq. }\end{array}$} & \multicolumn{2}{|c|}{ No violence $(n=839)$} & \multicolumn{2}{|c|}{$\begin{array}{l}\text { Low-moderate level } \\
\text { violence }(n=550)\end{array}$} & \multicolumn{2}{|c|}{$\begin{array}{c}\text { Severe violence } \\
\quad(n=146)\end{array}$} \\
\hline & & Freq. & $\%$ & Freq. & $\%$ & Freq. & $\%$ \\
\hline \multicolumn{8}{|l|}{ Age } \\
\hline$<24$ years & 289 & 166 & 57.4 & 106 & 36.7 & 17 & 5.8 \\
\hline $25-34$ & 544 & 301 & 55.3 & 197 & 36.2 & 46 & 8.5 \\
\hline $35-44$ & 491 & 270 & 55.0 & 167 & 34.0 & 54 & 11.0 \\
\hline $45-49$ & 211 & 102 & 48.3 & 80 & 37.9 & 29 & 13.7 \\
\hline M eans and standard deviation* & $33 \pm 9$ & $33 \pm 9$ & & $33 \pm 9$ & & $36 \pm 9$ & \\
\hline
\end{tabular}

Socioeconomic level

\begin{tabular}{llllllrr} 
Low & 394 & 201 & 51.0 & 145 & 36.8 & 48 & 12.2 \\
\hline Medium & 470 & 244 & 52.0 & 172 & 36.6 & 54 & 11.5 \\
\hline High & 671 & 394 & 58.7 & 233 & 34.7 & 44 & 6.6
\end{tabular}

Woman's education

\begin{tabular}{lrrrrrrr}
$<6$ years & 579 & 283 & 48.9 & 223 & 38.5 & 73 & 12.6 \\
\hline $7-9$ years & 470 & 258 & 54.9 & 171 & 36.4 & 41 & 8.7 \\
\hline$\geq 10$ years & 486 & 298 & 61.3 & 156 & 32.1 & 32 & 6.6 \\
\hline $\begin{array}{l}\text { Means and standard deviation* } \\
\begin{array}{l}\text { Partner's education } \\
<6 \text { years }\end{array}\end{array}$ & $8.4 \pm 4.0$ & $8.8 \pm 4.0$ & & $8.0 \pm 3.7$ & & $7.5 \pm 3.9$ & \\
\hline $7-9$ years & & & & & & & \\
\hline$\geq 10$ years & 478 & 242 & 50.6 & 181 & 37.8 & 55 & 11.5 \\
\hline Means and standard deviation* & 429 & 229 & 53.4 & 165 & 38.5 & 35 & 8.2 \\
\hline
\end{tabular}

Years living with partner

\begin{tabular}{lrrrrrrr}
$<5$ years & 399 & 256 & 64.2 & 120 & 30.1 & 23 & 5.8 \\
\hline 6 -10 years & 325 & 176 & 54.1 & 126 & 38.8 & 23 & 7.1 \\
\hline$\geq 11$ years & 697 & 364 & 52.2 & 261 & 37.4 & 72 & 10.3 \\
\hline Means and standard deviation* & $12.3 \pm 8.7$ & $11.6 \pm 8.7$ & & $12.6 \pm 8.5$ & & $14.8 \pm 9.2$ &
\end{tabular}

Partner's alcohol use

\begin{tabular}{lrrrrrrr} 
No & 673 & 460 & 68.3 & 178 & 26.4 & 35 & 5.2 \\
\hline Yes & 748 & 336 & 44.9 & 329 & 44.0 & 83 & 11.1 \\
$\begin{array}{l}\text { Partner's illegal drug use } \\
\text { No }\end{array}$ & & & & & & & \\
\hline Yes & 1384 & 786 & 56.8 & 491 & 35.5 & 107 & 7.7 \\
$\begin{array}{l}\text { Violence during childhood } \\
\text { No }\end{array}$ & 37 & 10 & 27.0 & 16 & 43.2 & 11 & 29.7 \\
\hline $\begin{array}{l}\text { Yes } \\
\text { History of rape }\end{array}$ & 1064 & 659 & 62.0 & 327 & 30.7 & 78 & 7.3 \\
$\quad$ No & 471 & 180 & 38.2 & 223 & 47.4 & 68 & 14.4 \\
\hline Yes & & & & & & & \\
\end{tabular}

$\mathrm{N}$ umber of pregnancies

\begin{tabular}{lrrrrrrr}
$0-1$ & 301 & 203 & 67.4 & 82 & 27.2 & 16 & 5.3 \\
\hline 2 & 359 & 206 & 57.4 & 129 & 36.0 & 24 & 6.7 \\
\hline$\geq 3$ & 430 & 430 & 49.1 & 339 & 38.7 & 106 & 12.1 \\
\hline Means and standard deviation* & $3.2 \pm 2.1$ & $3 \pm 2$ & & $3 \pm 2$ & & $4 \pm 3$ &
\end{tabular}

Age at first sexual intercourse

\begin{tabular}{lrrrrrrr}
$<17$ years & 525 & 233 & 44.4 & 223 & 42.5 & 69 & 13.1 \\
\hline $18-20$ years & 594 & 333 & 56.1 & 213 & 35.7 & 48 & 8.1 \\
\hline$\geq 21$ years & 416 & 273 & 65.6 & 114 & 27.4 & 29 & 7.0 \\
\hline Means and standard deviation* & $19.1 \pm 3.6$ & $20 \pm 4$ & & $19 \pm 3$ & & $18 \pm 3$ &
\end{tabular}

$*$ p value $<0.02$ 


\section{Factors associated With violence against women by their male partners. Cuernavaca, Morelos, MeXico, 1998}

\begin{tabular}{|c|c|c|c|c|c|c|c|c|c|}
\hline \multirow[b]{2}{*}{ Variables } & \multirow{2}{*}{$\begin{array}{l}\text { Total }(n=1421)^{*} \\
\text { Frequency }\end{array}$} & \multicolumn{2}{|c|}{$\begin{array}{l}\text { Low- moderate level } \\
\text { violence }(n=507)\end{array}$} & \multicolumn{2}{|c|}{$\begin{array}{c}\text { Severe } \\
\text { violence }(n=118)\end{array}$} & \multicolumn{2}{|c|}{$\begin{array}{c}\text { Low- moderate level } \\
\text { violence }(n=507)\end{array}$} & \multicolumn{2}{|c|}{$\begin{array}{c}\text { Severe } \\
\text { violence }(n=118)\end{array}$} \\
\hline & & & & & & & & & $(95 \% \mathrm{Cl})$ \\
\hline \multicolumn{10}{|l|}{ Age } \\
\hline$<24$ years & 284 & $1.0^{\#}$ & & & & $1.0^{\#}$ & & & \\
\hline $25-34$ years & 517 & 1.02 & $(0.75-1.39)$ & 1.36 & $(0.75-2.48)$ & 1.08 & $(0.79-1.50)$ & 1.45 & $(0.77-2.72)$ \\
\hline $35-44$ years & 452 & 0.92 & $(0.67-1.27)$ & 1.73 & $(0.96-3.12)$ & 1.02 & $(0.73-1.43)$ & 1.96 & $(1.05-3.67)$ \\
\hline $45-49$ years & 168 & 1.11 & $(0.74-1.67)$ & 1.49 & $(0.70-3.17)$ & 1.24 & $(0.81-1.91)$ & 1.83 & $(0.83-4.03)$ \\
\hline Test for trend & & & $p=0.90$ & & $p=0.12$ & & $p=0.67$ & & $p=0.05$ \\
\hline \multicolumn{10}{|c|}{ Socioeconomic level } \\
\hline Low & 356 & $1.0^{\#}$ & & & & $1.0^{\#}$ & & & \\
\hline Medium & 433 & 0.97 & $(0.71-1.30)$ & 0.97 & $(0.60-1.58)$ & 0.99 & $(0.72-1.36)$ & 1.09 & $(0.65-1.83)$ \\
\hline High & 632 & 0.82 & $(0.62-1.09)$ & 0.55 & $(0.34-0.89)$ & 0.83 & $(0.62-1.10)$ & 0.57 & $(0.34-0.95)$ \\
\hline test for trend & & & $p=0.08$ & & $p<0.001$ & & $p=0.11$ & & $p=0.002$ \\
\hline \multicolumn{10}{|c|}{ Woman's education } \\
\hline$<6$ years & 520 & $1.0^{\#}$ & & & & $1.0^{\#}$ & & & \\
\hline $7-9$ years & 448 & 0.87 & $(0.66-1.15)$ & 0.88 & $(0.66-1.15)$ & 0.89 & $(0.66-1.19)$ & 0.99 & $(0.60-1.62)$ \\
\hline$\geq 10$ years & 453 & 0.68 & $(0.51-0.90)$ & 0.53 & $(0.32-0.88)$ & 0.71 & $(0.53-0.96)$ & 0.58 & $(0.34-1.00)$ \\
\hline test for trend & & & $p=0.002$ & & $p=0.02$ & & $p=0.01$ & & $p=0.10$ \\
\hline \multicolumn{10}{|c|}{ Partner's education } \\
\hline$<6$ years & 478 & $1.0^{\#}$ & & & & $1.0^{\#}$ & & & \\
\hline $7-9$ years & 429 & 0.96 & $(0.73-1.27)$ & 0.67 & $(0.42-1.07)$ & 0.91 & $(0.67-1.24)$ & 0.67 & $(040-1.11)$ \\
\hline$>10$ years & 514 & 0.66 & $(0.51-0.87)$ & 0.38 & $(0.23-0.62)$ & 0.63 & $(0.47-0.85)$ & 0.37 & $(0.22-0.63)$ \\
\hline test for trend & & & $p=0.002$ & & $p<0.001$ & & $p=0.002$ & & $p<0.001$ \\
\hline \multicolumn{10}{|c|}{ Years living with partner } \\
\hline$<5$ years & 399 & $1.0^{\#}$ & & & & $1.0^{\#}$ & & & \\
\hline $6-10$ years & 325 & 1.53 & $(1.11-2.09)$ & 1.45 & $(0.79-2.67)$ & 1.54 & $(1.11-2.15)$ & 1.46 & $(0.77-2.78)$ \\
\hline$\geq 11$ years & 697 & 1.53 & $(1.17-2.00)$ & 2.20 & $(1.34-3.61)$ & 1.65 & $(1.24-2.20)$ & 2.63 & $(1.55-4.45)$ \\
\hline test for trend & & & $p=0.04$ & & $p<0.001$ & & $p=0.007$ & & $p<0.001$ \\
\hline \multicolumn{10}{|c|}{ Partner's alcohol use } \\
\hline No & 673 & $1.0^{\#}$ & & & & $1.0^{\#}$ & & & \\
\hline Yes & 748 & 2.54 & $(2.01-3.19)$ & 3.33 & $(2.18-5.01)$ & 2.56 & $(2.02-3.25)$ & 3.47 & $(2.23-5.40)$ \\
\hline \multicolumn{10}{|c|}{ Partner's illegal drug use } \\
\hline No & 1384 & $1.0^{\#}$ & & & & $1.0^{\#}$ & & & \\
\hline Yes & 37 & 2.56 & $(1.15-5.69)$ & 8.69 & $(3.58-21.06)$ & 2.17 & $(0.95-4.95)$ & 6.17 & $(2.37-16.03)$ \\
\hline \multicolumn{10}{|c|}{ Violence during childhood } \\
\hline No & 982 & $1.0^{\#}$ & & & & $1.0^{\#}$ & & & \\
\hline Yes & 439 & 2.58 & $(2.02-3.30)$ & 3.78 & $(2.53-5.63)$ & 2.61 & $(2.03-3.36)$ & 3.40 & $(2.23-5.18)$ \\
\hline \multicolumn{10}{|l|}{ History of rape } \\
\hline No & 1372 & 1.0 & & & & 1.0 & & & \\
\hline Yes & 49 & 1.30 & $(0.64-2.67)$ & 8.08 & $(4.02-16.20)$ & 1.03 & $(0.49-2.16)$ & 5.89 & $(2.78-12.51)$ \\
\hline \multicolumn{10}{|c|}{ N umber of pregnancies } \\
\hline $0-1$ & 280 & $1.0^{\#}$ & & & & $1.0^{\#}$ & & & \\
\hline 2 & 340 & 1.68 & $(1.17-2.41)$ & 1.45 & $(0.73-2.86)$ & 1.62 & $(1.10-2.37)$ & 1.51 & $(0.74-3.07)$ \\
\hline$\geq 3$ & 801 & 2.32 & $(1.63-3.31)$ & 2.26 & $(1.18-4.32)$ & 1.66 & $(1.13-2.45)$ & 1.32 & $(0.65-2.65)$ \\
\hline test for trend & & & $p<0.001$ & & $p<0.001$ & & $p=0.001$ & & $p=0.06$ \\
\hline \multicolumn{10}{|c|}{ Age at first sexual intercourse } \\
\hline$<17$ years & 481 & $1.0^{\#}$ & & & & $1.0^{\#}$ & & & \\
\hline $18-20$ years & 561 & 0.68 & $(0.53-0.88)$ & 0.50 & $(0.32-0.77)$ & 0.78 & $(0.59-1.03)$ & 0.65 & $(0.40-1.06)$ \\
\hline$\geq 21$ years & 379 & 0.45 & $(0.33-0.60)$ & 0.34 & $(0.20-0.58)$ & 0.63 & $(0.45-0.90)$ & 0.64 & $(0.35-1.17)$ \\
\hline test for trend & & & $p<0.001$ & & $p<0.001$ & & $p=0.01$ & & $p=0.03$ \\
\hline \multicolumn{10}{|c|}{$\begin{array}{l}\text { * The } 1421 \text { women who had a partner at the time of the study were included in the analysis } \\
\text { \& OR adjusted only by age } \\
\text { \& } O R \text { adjusted by the variables contained in the table } \\
\text { \# Reference category }\end{array}$} \\
\hline Note: For the $d e$ & riable, the no viol & tegory & $=796)$ was ta & as the & ference & & & & \\
\hline
\end{tabular}


hol and drug use, history of violence during childhood, and history of rape.

The majority of the women who had been attacked by their partner fought back against these aggressions $(63 \%)$. Of those women who had communicated with others about the violence they experienced $(n=391)$, $67 \%$ did so with their families, $24 \%$ with friends, and the rest with another person. In terms of protective measures taken by women who are victims of violence, the largest number responded that they tried to solve the problem with their partner $(44 \%)$. A significant percentage of women responded that they had not taken any steps because they thought they would not experience violence from their partner again $(34 \%)$, while only $2 \%$ sought professional help.

\section{Discussion}

The present results suggest that male partner violence against women is a prevalent phenomenon in Mexico. The prevalence found in our study is similar to that reported by other studies carried out in Mexico and Latin America, in general, where prevalence estimates vary from $30 \%$ to $60 \% .^{3-6,15,21,22}$ Nevertheless, comparative analysis of violence against women is not easy, since a wide variety of definitions and methodologies have been used to study it. Furthermore, socio-cultural factors that influence this phenomenon may differ across social and cultural groups. In this study, the authors decided to analyze violence primarily at two levels of severity (low and severe). Although this measure is admittedly imperfect, variation in the strength of the risk factors across levels of violence severity support the validity of our measures. Moreover, the validity of our measures is supported by similar results reported by other authors who measure violence differently.

It is significant that the prevalence registered in our study is almost two-fold higher than that of studies carried out in developed countries. ${ }^{9114,16,23,24}$ Future research should determine the factors accounting for such variation. At present we can only hypothesize about which factors might contribute to this problem. One factor could be that violence against women has become a subject of public concern and discussion in Mexico only recently, while in developed countries it has been the object of research and intervention efforts for a number of years. Also, in Mexico, and specifically in the state of Morelos, where this study was carried out, laws penalizing violence against women have only recently been passed (in 1999), while equivalent legislation has existed for much longer in many developed countries. This is not to imply that legislation is suffi- cient, in and of itself, to solve the problem of gender violence. It is likely, however, that the existence and implementation of related laws is accompanied by the development of a greater awareness of the problem in society as a whole. Such laws may facilitate the wider reach of campaigns that empower women in this aspect of their lives, a kind of empowerment that, to a great extent, is still lacking in Mexico. ${ }^{25,26}$ The results of this study, especially the finding that very few battered women sought legal and professional help (only $2.2 \%)$, support the notion that recently passed legislative efforts to combat gender violence in Mexico have not had a significant impact.

This study also found that $5.9 \%$ of the women reported having been raped by a non-partner and $11 \%$ reported being forced to have sexual intercourse with their partner against their will. The fact that $27 \%$ to $62 \%$ of US women report rape by a non-partner ${ }^{2,27}$ leads to wondering whether the women in our sample underreported their experience. Reporting could be influenced by the fact that victims tend to fear taking their aggressors to court, in spite of the existence of laws penalizing rape in Mexico; this is understandable because some of the victims are threatened or stigmatized. ${ }^{27}$ Moreover, although Mexico is among the relatively few countries with legislation against marital rape, sexual abuse or rape by a partner is often not perceived as a crime by the woman herself. ${ }^{9}$ This is a complex issue that must be analyzed in terms of gender inequalities in each society. ${ }^{28-29}$

The findings of our study are consistent with those of studies that have found associations between violence and low socioeconomic status..$^{6,10,11,17}$ However, this finding may be due to people with higher socioeconomic status, whether they are the aggressor or the victim, having more access to privacy. ${ }^{10-18}$ Nevertheless, in spite of important differences between socioeconomic status groups, it is important to recognize that violence also occurs in groups with higher educational and economic resources. One very general explanation is that in spite of women's impressive but relatively recent access to education and paid employment, enormous gender inequalities persist in relation to many aspects of women's lives, which contributes to the continuing problem of gender violence. ${ }^{2}$

Our results also concur with those from studies that have shown that alcohol and drug use by the male partner are important risk factors for violence against women. ${ }^{10,12-13,15,17,23}$ However, we agree with the idea, often repeated in the literature, that alcohol and drug use weakens the individual's inhibitions and can contribute to the manifestation of violence, but is not the root cause of it. Nevertheless, an important strategy 
for lowering the level of gender violence is to strengthen and extend programs for preventing or treating alcohol and drug use.

Other studies have shown that frequently, both men who batter their partners and women who undergo gender violence have been the victims or witnesses of violence in their families of origin. ${ }^{12-14}$ Our study only analyzed a history of violence among the women (not among men, who were not interviewed), but it did find an important correlation between such a history and current violence by the male partner $(\mathrm{OR}=3.40)$.

Some researchers have found that women who were victims of sexual abuse during childhood have a greater risk of violence during their adult relationships, as compared with women with no such childhood history. ${ }^{2-11}$ We also found an important association between women who were victims of sexual abuse during childhood and those whose partners inflicted severe violence on them $(\mathrm{OR}=5.89)$. One hypothesis is that victims of early sexual abuse are left with fewer skills for protecting themselves, perhaps feel less sure of their self-worth, and have a less clear definition of their personal limits, and therefore are more vulnerable to victimization. These could be among the factors that increase the possibilities of future victimization. ${ }^{30}$

\section{Limitations}

One limitation of this study is that it had a cross-sectional design, thus causality cannot be established. However, with the results obtained we can generate hypotheses. In addition, the results only represent women 15 to 49 years of age who have had male partners. Finally, it is likely that partner alcohol and illegal drug prevalence in this study is underestimated, given that the partners themselves were not questioned. Nevertheless, this error would have been random since the question was asked in the same way for the whole study population.

\section{Conclusions}

This study contributes to the literature on gender violence, providing further evidence that it is a complex phenomenon, deeply rooted in power relations related to gender, sexuality, personal identity, and social institutions. The results indicating relatively high levels of violence and low levels of service utilization suggest that raising awareness in the general population may be necessary to bring gender violence to the forefront of public discussion as an important issue. Efforts must be made to warrant that future generations of Mexican women do not experience this level and intensity of gender violence. Given that violence is more frequent among women whose partners abuse alcohol and drugs, prevention programs for these addictions should be reinforced and extended, especially for young people, so as to lower violence levels in future partnerships. Campaigns should teach young women and girls to protect themselves from aggressors and rapists, while promoting the laws that protect people from sexual or physical violence. Finally, future studies about violence should include men as participants. Research on men who perpetrate violence is needed to formulate truly effective strategies for reducing gender violence.

\section{Acknowledgements}

This study was made possible by the support of the National Institute of Public Health, in Cuernavaca, Morelos, Mexico.

\section{References}

1.W orld Health 0 rganization. Violence against women: Legislation. Geneva:W HO ;2000:5.

2. Heise L, Pitanguy J, Germain A.Violence against women:The hidden health burden.W ashington, DC:W orld Bank; 1994. (D iscussion Paper N 0.255$)$.

3. Ramírez-Rodríguez JC, Vargas-Becerra PN . U na espada de doble filo: la salud reproductiva y la violencia doméstica contra la mujer. [A double-edged sword: Reproductive health and domestic violence against women]. Proceedings of the Seminar "Salud Reproductiva en A mérica Latina y el Caribe:Temas y Problemas"; C axambú, MG , Brasil; 1996:24. 4.Valdez R, Sanín L. La violencia doméstica durante el embarazo y su relación con el bajo peso al nacer. Salud Publica Mex 1996;38:352-362. 5. Centro de Investigación y Lucha contra laViolencia D oméstica. Aún la luna tiene miedo. Una aproximación a la violencia doméstica en México. México, DF:CECOVID; 1992.

6. 0 livar rieta C, Sotelo J. Domestic violence in Mexico. JA MA 1996;275:1937-1941.

7. Hudson W, McIntosh S.The assessment of spouse abuse:Two quantifiable dimensions. J Marr Fam 1981;43:873-885.

8. Straus M, Hamby S, Mc C oy S, Sugarman D.The revised conflict tactics scales (CTS2). J Fam Issues 1996;17:283-316.

9. UN ICEF. D omestic violence against women and girls. Preliminary edition; UN IC EF Innocenti Research Center N 0. 6; Roma: UN ICEF; 2000. 10. Buvinic M, Morrison A, Shifter M. La violencia en las Américas: marco de acción. En: Morrison A, Loreto M, ed. El costo del silencio.Violencia doméstica en las A méricas. W ashington, DC: Banco Interamericano de Desarrollo; 1999:3-34.

11. Stark E, Flitcraft H. Spouse abuse. En:Violence in America:A public health approach. N ew York (N Y): 0 xford University Press; 1991.

12. Aldarondo E, Sugarman D. Risk marker analysis of the cessation and persistence of wife assault.J Consult C lin Psychol 1996;64:1010-1019. 13. Mullen PE, Martin JL,Anderson JC, Romans SE, Herbison G P.The long-term impact of the physical, emotional and sexual abuse of children:A community study. Child Abuse N eglect 1996;20:7-21. 
14. Plichta SB,A braham C.Violence and gynecologic health in women $<50$ years old. Am J O bstet Gynecol 1996;174:903-907. 15. Ellsberg M, Peña R, Herrera A, Liljestrand J,W inkvist A.W ife abuse among women of childbearing age in $\mathrm{N}$ icaragua. Am J Public Health 1999:89:241-244

16. McC auley J, Kern D, Kolodner K, Dill L, Schroeder A, D e Chant H et al. The "Battering Syndrome": Prevalence and clinical characteristics of domestic violence in primary care internal medicine practice.Ann Intern Med 1995;123:737-746.

17. O 'Campo P, Gielen A, Faden R, X ue X, Kass N , W ang MC.Violence by male partners against women during the childbearing year: $A$ contextual analysis. Am J Public Health 1995; 85:1092-1097.

18. Kyriacou D, McC abe F,Anglin D, Lapesarde K,W iner MR. Emergency department-based study of risk factors for acute injury from domestic violence against women.Ann Emerg Med 1998; 31:502-506. 19. Lazcano P, Moss S, C ruz A,Alonso P, Casares S, Martínez J et al. Factores que determinan la participación en el tamizaje de cáncer cervical en el estado de Morelos. Salud Publica Mex 1999;41:278-285.

20. Lazcano P, Herrero R, Muñoz N, Cruz A, Shah KV,Alonso P. Epidemiology of HPV infection among Mexican women with normal cervical cytology. Int J C ancer 2001;91:412-420.

21. Saucedo I.Violencia doméstica y salud: avances y limitaciones para la investigación y atención. En: IV Congreso Latinoamericano de Ciencias Sociales y Medicina; 1997 junio 2-6; Cocoyoc, Morelos, México.

22. Venguer T, Fawcett $G$,Vernon R, Pick S.Violencia doméstica: un marco conceptual para la capacitación del personal de salud. México, DF: Population Council, IN O PAL III: 1998;24:7-52.
23. 0 riel K, Fleming M. Screening men for partner violence in a primary care setting.A new strategy for detecting domestic violence.J Fam Pract 1998:46:493-498.

24. Ratner P.The incidence of wife abuse and mental health status in abused wives in Edmonton, Alberta. Rev C an Santé Publique 1993:84:246-249.

25. Comisión $\mathrm{N}$ acional de Derechos Humanos. La violencia intrafamiliar en México.Aporte en favor de una solución legislativa. México, DF: Comisión N acional de Derechos Humanos; 1996.

26. Ley de Prevención y Asistencia de laViolencia Intrafamiliar para el Estado de Morelos, 1999.

27. Figueroa J, Rivera G. Algunas reflexiones sobre la representación social de la sexualidad femenina. En: Mujeres y relaciones de género en la antropología latinoamérica. México, DF:El Colegio de México; 1993:141-167

28. Batliwala S. El significado del empoderamiento de las mujeres: nuevos conceptos desde la acción. En: León $M$, ed. Poder y empoderamiento de las mujeres. Santa Fe de Bogotá: Facultad de Ciencias Humanas; 1997:187-211.

29. Sayavedra G, Flores E. Algunas reflexiones teóricas. En: Sayavedra G, Flores E, ed. Ser mujer: ¿un riesgo para la salud? Del malestar y enfermar, al poderío y la salud. México: Red de Mujeres; 1997:62-91. 30. Koss M.The women's mental health research agenda:Violence against women. Am Psychol 1990;45:374-380. 


\section{A ppendix 1}

IN THE LAST YEAR THAT YOU WERE WITH YOUR PARTNER, HOW OFTEN DID HE DO THE FOLLOWING?

Items

1.- He wouldn't give you money, or he took your money

2.- He tried to control you in your activities

3.- He prevented you from going to school or work

4.- He insulted you, swore at you or humiliated you verbally

5.- He destroyed things which belonged to you

6.- He threatened to hit you with his fists

7.- He threatened to hurt you or your family or friends

8.- He threw something at you which could have hurt you

9.- He pushed or shook you

10.- He slapped you

11.- He kicked you, bit you or hit you with his fist

12.- He hit you with an object

13.- He beat you up

14.- He hurt you badly enough that you needed medical attention

15.- He hurt you badly enough that you could not carry out your work or daily activities

16.- He tried to strangle you

17.- He forced you to have sexual relations or perform sexual acts when you did not want to

18.- He burned you

19.- He locked you up

20.- He threatened you with a knife or gun

21.- He threatened to kill you

22.- He cut you with a knife or shot at you with a gun

N ote: 1 (never), 2 (rarely), 3 (regularly), 4 (very often)
(1)

(2)

(3)

(4) 